\title{
Collaborative Networks Model for Clothing and Footwear Business Sector
}

\author{
João Bastos $^{1}$, Valentina Franchini ${ }^{2}$, Américo Azevedo ${ }^{1}$, and Rosanna Fornasiero ${ }^{3}$ \\ ${ }^{1}$ INESC TEC (formely INESC Porto) \& Faculdade de Engenharia da Universidade do Porto, \\ Rua Doutor Roberto Frias 378, 4200-465 Porto, Portugal \\ \{joao.bastos, ala\} @ fe.up.pt \\ ${ }^{2}$ University of Padova Enterprises, Stradella San Nicola 3, 36100 Vincenza, Italy \\ franchini@gest.unipd.it \\ ${ }^{3}$ ITIA-CNR -Institute of Industrial Technologies and Automation -National Council of \\ Research, Via Bassini 15, 20133 Milano, Italy \\ rosanna.fornasiero@itia.cnr.it
}

\begin{abstract}
In clothing and footwear business sector, consumer needs and expectations of specific target groups - such as elderly, obese, disabled, or diabetic persons - are arising as challenging opportunities for European companies that are asked to supply small series of innovative and fashionable goods of high quality, affordable price and eco-compatible. This paper aims at propose a three level (strategic, tactical, and operational) reference model to support the Textile, Clothing and Footwear (TCF) collaborative supply networks in addressing the need for Fashionable and Healthy Clothing \& Footwear products.
\end{abstract}

Keywords: Reference Model, Supply Networks, Collaborative Networks, Clothing and Footwear.

\section{Introduction}

The recent years have stressed the need to re-invent the concept of enterprise. Since 2008, with the global financial crisis coupled with the remarkable increase of oil and energy prices, the way to make business have changed dramatically. The flow of money decreased and consequently the flow of products and services have changed dramatically. Enterprise managers are now forced to address the market and especially the individual customer with augmented care by putting more emphasis on the service levels they provide, by reducing response times and by tackling the specific needs of the diversity of customers. This confluence of trends has led managers moving from a traditional functional focus in the way they conduct business into a more holistic approach in the manner they address the supply chain. As consequence, it is emerging at industrial level an adoption of collaborative strategies addressing the small series production of high-customized complex products with increased emphasis in the service levels and the reduction of the response times. Along this vein, consumer needs and expectations of specific target groups - such as 
elderly, obese, disabled, or diabetic persons - are arising as challenging opportunities for European companies which are asked to supply small series of innovative and fashionable goods of high quality, affordable price and eco-compatible in short periods of time and with high service levels. In order to design, develop, produce and distribute such products, a new framework and related components of collaborative networking are necessary.

The main objective of this research, framed within the EU (European Union) funded project CoReNet, is to present an innovative Reference Model for the TCF SMEs (small and medium enterprises) companies in collaborative networks to support the manufacturing of small batches of products addressing the need of the special consumer target groups. The aim of this new reference model is to equip fashionable and healthy footwear \& garments network managers and stakeholders with the necessary guidance to model, design and configure the combination of processes, functions, activities, relationships and pathways along which products, services and information move in and between TCF companies.

The remaining of this paper is organized as follows: first the existing related literature is shown, followed by a presentation about multiple case studies conducted within footwear companies to single out and study distinctive practices and processes. Finally, based both on literature review and within and cross case analysis, a comparison between the distinctive practices and relevant processes in the TCF industry is presented in order to highlight the best practices and add new knowledge to the sector.

\section{Foundations and Research Topics}

In order to address the new type of target groups (elderly, obese, disabled, or diabetic persons) demand, it is necessary to develop new collaborative supply chain solutions based on cost effective, social compliant and eco-efficient design and production of customized products that fully satisfy the customers, considering their health issues as well as their desire for fashionable products.

Recent research in the field addressed different forms of business networks. The literature distinguishes for example by value chain orientation (horizontal, vertical, lateral), life span (long-term vs. short-term), and degree of virtualization or hierarchical structure (hierarchical vs. non-hierarchical networks) [2]. Nevertheless, the most common business networks are formed along the value chain and for enduring purposes [3].

At the same time, the current market trends calls for flexibility at the supply network level, the processes and the product designs in order to empower the companies to quickly adapt for new business requirements and sustainability challenges. This new demands are forcing business networks to have much shorter life-time existence and take advantage of new infrastructure technologies supported in distributed information systems and knowledge [4].

The new concept of demand-driven supply networks is emerging in literature as a collaborative approach in response to consumer's needs and expectations [5,6]. In 
reality, many companies that embrace this paradigm transformed their operating systems from the traditional functional supply networks through a holistic approach that addresses demand in all of its dimensions. This implies different approaches to the market based not only on traditional sales channels (shops, retailers) but more and more on an Internet mediated direct contact with consumers equally for product conception, for product sales but also for after-sales services.

Simultaneously, the market increasingly values collaborative networks that endorse the sustainability challenges. These networks by seeing the world's present and future challenges seek to develop new products and processes that can be part of the solution. Namely, through a holistic view of the supply network it is possible to measure and optimize the overall impact of the "carbon footprint", to implement policies that seek recycling and waste prevention, product design for sustainability and the use of emerging clean technologies [4]. From the production viewpoint, companies from different sectors in sustainable networks need to integrate their production systems in order to offer to the customer integrated solutions and innovative services and products.

A deep analysis of some of the most important supply network reference models present in literature - among others: Value reference model, SCOR model and Y-Cim model - have shown the applicability of the SMART model proposed by Filos and Banhan [9] as starting point for the definition of the Fashionable and Healthy Clothing \& Footwear reference model for supply networks. The SMART model allows the definition of practices, technological and performance models for collaborative networks according to the following three main dimensions:

1. Knowledge dimension - to map partners' competencies to be shared within the network in terms of products and processes;

2. Information \& Communication Technologies (ICTs) dimension - to support the requirements for the implementation of ICT services at different process levels along the network;

3. Organizational dimension- to provide specifications of the organizational changes for SMEs for structuring supply networks in small series production.

In order to make the reference model for the TCF European companies cope with the environmental consciousness, the present reference model approach used the SMART model proposed by Filos and Banhan [9] and additional presented a new dimension, coherent with eco-efficiency objective, the Sustainability dimension. This new dimension is intended to support the enterprises in the developing of an ecocompatible approach for their products and processes.

A set of companies belonging to the TCF sector has been selected to conduct multiple case studies to investigate this new research field, within textile, clothing and footwear companies in order to identify and investigate distinctive practices and processes suitable for characterising the Reference Model proposal. The sample was selected adopting theoretical sampling [10], and multiple investigators are used to reduce bias and create more reliable data $[11,12]$.

An "as is" business process analysis was conducted through focused interviews and BPMN (Business Process Modelling Notation) representation to collect and 
formalize a rich set of data, both qualitative and quantitative. Furthermore, the requirements of each company were pointed out and analysed in detail to draw the relevant characteristics, procedures and techniques along their supply constellation.

Within-case analyses allowed the study of each individual company singularly and understand their requirements in terms of the four dimensions, while a cross-case analysis among the different companies allowed the comparison of the companies' behaviour and understand their collaboration mechanisms.

\section{Reference Model for TCFI Collaborative Networks}

The research project CoReNet (Customer-Oriented and Eco-friendly Networks for Health Fashionable Goods) $[13,14]$, intends to support textile, clothing and footwear companies in the implementation of new models for small series production for health and fashionable goods. Furthermore it follows the Competitive Sustainable Manufacturing (CSM) paradigm [15] and current initiatives of European Technological Platforms like Manufuture [16] and Footwear. The project intends to support the whole value chain to get and manage consumer data to investigate its needs; involve consumer into design and product configuration phases; exchange consumer data through adequate data models and secure systems; manage the collaboration with suppliers in order to plan and distribute on time; implement innovative manufacturing technologies; deliver timely the product to customer; and monitor the quality and sustainability of products. This approach aimed to develop a systematic strategy for the supply network configuration, coupled with a detailed definition and characterization of the operative level of processes and activities along four main dimensions (Knowledge, ICT, Organizational and Sustainability).

The Reference Model enhances the TCF companies in addressing specific target groups by enabling them in producing healthy and fashionable products in a collaborative environment. The base ground for the model was based in a comprehensive literature review and case-analysis field work.

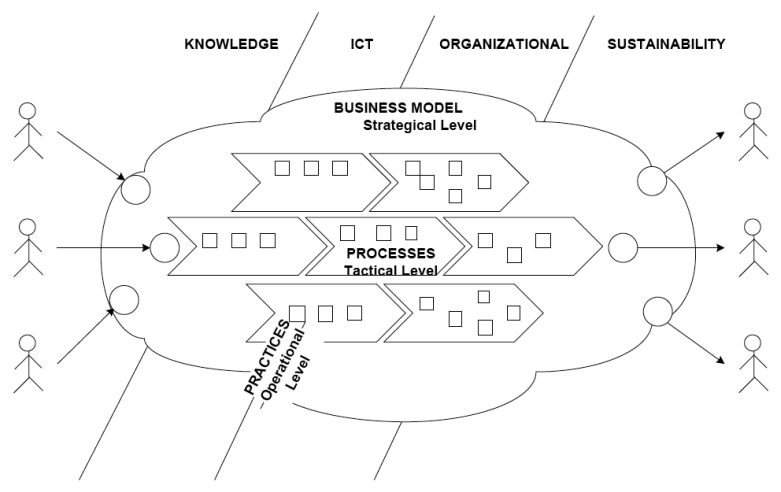

Fig. 1. Reference Model Context Diagram 
As depicted in Fig.1 diagram the Reference Model will support TCF companies at strategic level covering the overall collaboration framework of the supply chain, at tactical level with the support to the definition of the processes which emerged as relevant for this kind of business and at the operational decision level by presenting rules and "best practices" to align the material flow to the specific market needs. In the following sections it will be detailed these three levels.

\subsection{Strategic Level}

Regarding the strategic level, the business model framework proposed by Osterwalder [17] was applied as conceptual approach. The model maps the most important building blocks that influence the definition of the value proposition. The idea is to instantiate the model to the specific case of TCF sector. Osterwalder [18] widens this concept and defines Business Models as: "...a conceptual tool that contains a set of elements and their relationships and allows a company's logic of earning money. It is a description of the value a company offers to one or several segments of customers and the architecture of the firm and its network of partners for creating marketing and delivering this value and relationship capital, in order to generate profitable and sustainable revenue streams".

In this regard, it is understood that business models should not only comprise the perspective inside organizations, but also embrace a wider perspective that includes potential partnerships, customers' requirements, revenue shares and other elements. A graphical representation merging the models presented by Ostervalder and (improved by) Romero et al. [19], as well as the empirical-based marketing approaches developed by Plantin [20] is shown in Figure 2. It is important to mention that this amalgamated representation is in accordance with Chesbrough and Rosenbloom [21] proposition, where a business model is placed as a linking ingredient between technical inputs (infrastructure management) and economical outputs (customer interface and financial aspects).

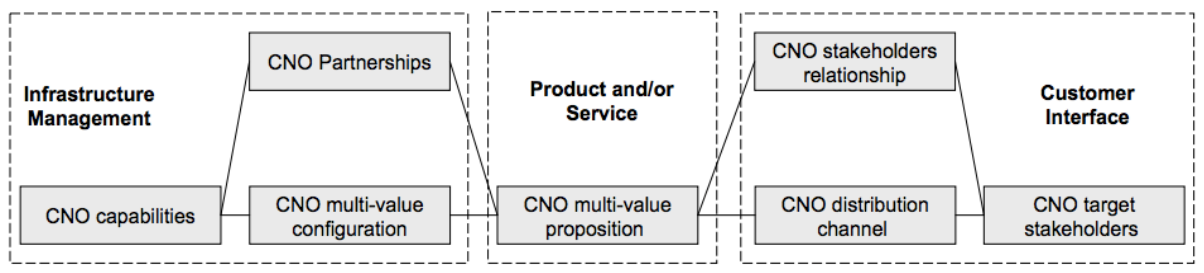

Fig. 2. Supply chain strategy based on building blocks

In collaborative endeavours, and therefore co-creation environments, value propositions are common ground between collaborative-networked organizations and customer communities. Collaborative networks should combine the capabilities of their members to create new abilities to better support the personalization of experiences and with customer knowledge synergies co-create real personal value 
propositions where the consumer is starting to play an increasingly important role in the co-construction of value offers [22].

Following this perspective, Table 1 depicts the most important features of the building blocks for the business model of healthy and fashionable SMEs. In addition the dimensions involved in each building block are identified. The most important characteristics that differentiate healthy and fashionable SMEs from the traditional footwear companies is the direct contact via web with final customers, that gives to small and medium manufacturers the possibility to understand customers needs without intermediaries and easily create best-fit configurations to fulfil their requirements. In order to allow firms to achieve this result it is fundamental to implement the right infrastructures in the companies, basing on the four dimensions of the Reference Model. In particular: knowledge on the requirements of target groups, ICT infrastructure to support the whole business model, organizational aspects to manage the supply network and sustainability to guarantee competitive advantages along the time.

Table 1. Building blocks for traditional SME and healthy and fashionable SME

\begin{tabular}{|c|c|c|}
\hline & Healthy and Fashionable SMEs & Dimensions involved \\
\hline $\begin{array}{l}\text { Target } \\
\text { stakeholders }\end{array}$ & $\begin{array}{l}\text { B2C: End consumer from target groups } \\
\text { B2B: Shops }\end{array}$ & Knowledge - ICT \\
\hline $\begin{array}{l}\text { Multi-value } \\
\text { proposition }\end{array}$ & $\begin{array}{l}\text { Healthy and fashionable best fit shoes and } \\
\text { garments produced and distributed in } \\
\text { collaborative environment }\end{array}$ & $\begin{array}{l}\text { Knowledge }- \text { ICT }- \\
\text { Organizational }- \text { Sustainability }\end{array}$ \\
\hline $\begin{array}{l}\text { Distribution } \\
\text { channel }\end{array}$ & $\begin{array}{l}\mathrm{B} 2 \mathrm{C} / \mathrm{B} 2 \mathrm{~B}-\mathrm{e}-\text { commerce } \\
\mathrm{B} 2 \mathrm{C} \text { - traditional shops }\end{array}$ & ICT - Organizational \\
\hline \multirow[t]{2}{*}{$\begin{array}{l}\text { Stakeholder } \\
\text { relationship }\end{array}$} & $\begin{array}{l}\text { Periodic fit sessions to define and adjust } \\
\text { configuration space (of variants) according } \\
\text { target groups' needs }\end{array}$ & \multirow[t]{2}{*}{ Knowledge - Organizational } \\
\hline & $\begin{array}{l}\text { Direct electronic communication to end- } \\
\text { consumer using internet interface and feedback }\end{array}$ & \\
\hline \multirow[t]{2}{*}{ Capabilities } & $\begin{array}{l}\text { Market analysis based on Data from Knowledge } \\
\text { Management Tools (KMT) supporting the } \\
\text { definition of the configuration space }\end{array}$ & \multirow[t]{2}{*}{ Knowledge - Organizational } \\
\hline & $\begin{array}{l}\text { Made-To-Measure sizing technology and } \\
\text { knowledge }\end{array}$ & \\
\hline $\begin{array}{l}\text { Multi-value } \\
\text { configuration }\end{array}$ & $\begin{array}{l}\text { Management of Made-To-Measure products } \\
\text { design }\end{array}$ & Knowledge - ICT \\
\hline Partnerships & $\begin{array}{l}\text { Management of the Made-to-Measure } \\
\text { manufacturing and delivery along the CNO } \\
\text { with: } \\
\text { Suppliers (raw materials and components) } \\
\text { Outsourcers } \\
\text { Service Providers } \\
\text { Technology providers } \\
\text { Customers belonging to Target groups } \\
\text { Communities }\end{array}$ & ICT - Organizational \\
\hline
\end{tabular}

\subsection{Tactical Level}

From the case-studies analyses a set of critical processes emerged as important to satisfy collaboration business requirements at network level. These processes have 
been mapped and formalized in a BPMN (Business Process Model Notation) representation [13] as presented in figure 3 .

The overall tactical level of the model is based on a customer-oriented approach to the supply network configuration. The starting point of the overall process is twofold according to the level of customization/configuration it is decided for the Target groups. On one side, the processes IM1 and IM2 represent the starting point from the customer. Traditional shopping as well as online configurators and customer profiling for specific customer groups are taken into consideration. IM1 and IM2 allow direct customer interaction on footwear, textiles or clothing products with special features for the consumer target groups (elderly, obese, diabetics and disabled people) with the possibility of product configuration and full visualization of products characteristics. From IM1 and IM2 it is possible to go to CD3.

On the other side, Co-design with Knowledge Management Tools (CD1) supports the identification of market needs and consumer preferences for new products and functionalities in CD2. Another important process is the Definition of Product Collection (CD2) for specific target groups based on collaborative environment where different type of users (internal and external to the company) with different roles can contribute to define a collection of suitable products for the target consumers. Regarding the small series production, it has been defined the Product Design process with CAD modelling (CD3) which is carried out by the (internal and external) designer and outcomes the CAD technical model of the product. Also includes selection of materials for both clothing and footwear.

Process planning (CD4) is related to product engineering and has the aim to decide how to manufacture the product and to generate all related information. In this phase suppliers and outsourcers are identified and defined and the costs for the different manufacturing phases are determined. Also the BOM, the working cycles and the production times of the new product model are also defined.

Customer order processing support (CP1) is based on automatic pre-processing of customer orders for administrative and pre-production checks and issues. The final output is the list of customer orders ready to be processed for production. With collaborative process planning (CP2) all standard and default data can be uploaded to the early (automatic) set of Production Orders; external activities (to be outsourced) require the identification of potential partners to be assigned. The output is the set of production orders ready to be scheduled. In Collaborative production planning and control (CP3) production orders related to the same customer's orders can be scheduled using a collaborative tool where manufacturer and partners inside the collaborative network can share a view of the production order schedules and close a "negotiation" for the definitive launch of manufacturing activities.

Last, the cross-cutting process of partner monitoring and trace support aims to monitor production orders as well as KPI related to Quality and Sustainability. The outcome includes overall status, alerts/warnings and high-level KPIs. For each of these processes a detailed description has been developed including information related to the flow of activities and related to the four dimensions of the model. 


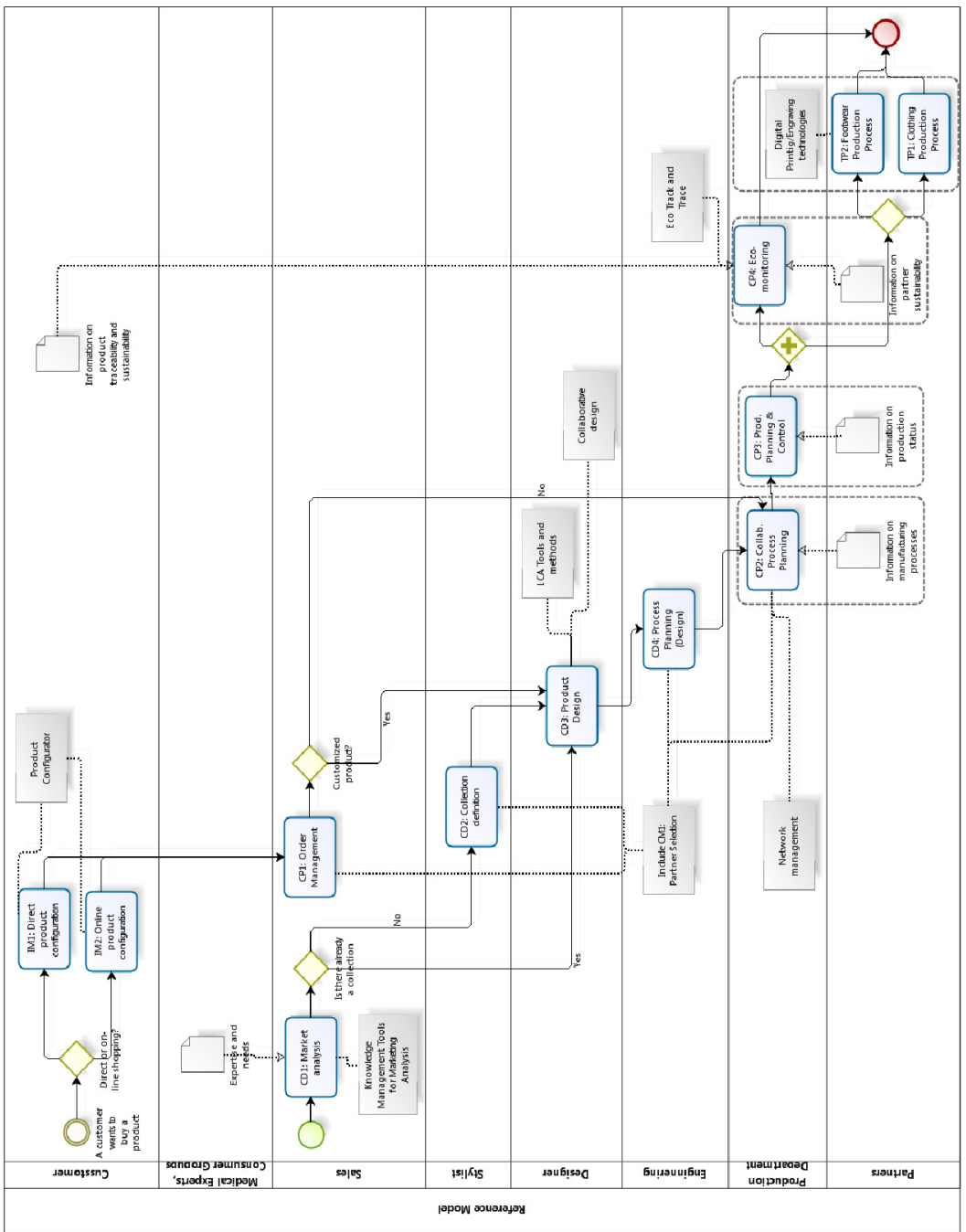

Fig. 3. BPMN representation of the mapped processes

\subsection{Operational Level}

Regarding the Operational Level it has been identified a set of practices that define the relationships between the tactical level and the four main dimensions and establish guidelines for the operational level decision making. An excerpt of the vast list of these Reference Model rules and operational best practices is presented in Table 2. 
Table 2. Excerpt of Operational Level table

\begin{tabular}{|c|c|c|c|c|}
\hline \multicolumn{5}{|c|}{ SALES/CONFIGURATION PROCESS } \\
\hline $\begin{array}{c}\text { BUSINESS } \\
\text { REQUIREMENTS }\end{array}$ & \multicolumn{2}{|c|}{$\begin{array}{l}\text { IM1 - Traditional shopping support for specific } \\
\text { customer groups }\end{array}$} & \multicolumn{2}{|c|}{$\begin{array}{l}\text { IM2 - Online visualization, configuration and } \\
\text { acquisition of leather/footwear }\end{array}$} \\
\hline KNOWLEDGE & \multicolumn{2}{|c|}{$\begin{array}{c}\text { Customer involvement. Customer requirements } \\
\text { management. Clinical aspect and functional } \\
\text { requirements. }\end{array}$} & \multicolumn{2}{|c|}{$\begin{array}{l}\text { Formalized knowledge of information needed } \\
\text { for the customer to assess the performance of } \\
\text { the product. }\end{array}$} \\
\hline ICT & \multicolumn{2}{|c|}{$\begin{array}{l}\text { Availability of machines like scanners, cameras, virtual } \\
\text { mirrors, etc.. able to get images, 3D rendering of } \\
\text { feet \bodies for product design. }\end{array}$} & \multicolumn{2}{|c|}{$\begin{array}{c}\text { It is necessary to create a clear and single } \\
\text { access point that customers can recognize as } \\
\text { online shop. }\end{array}$} \\
\hline ORGANIZATIONAL & \multicolumn{2}{|c|}{$\begin{array}{l}\text { In a customer driven supply chain, end-user demand } \\
\text { drives all activities among trading partners according } \\
\text { to a culture that puts the customer first. }\end{array}$} & \multicolumn{2}{|c|}{$\begin{array}{l}\text { Some steps realized by downstream supply } \\
\text { chain actors can be reduced compared to } \\
\text { direct sales. }\end{array}$} \\
\hline SUSTAINABILITY & \multicolumn{2}{|c|}{$\begin{array}{l}\text { Commitment with the customer to give information } \\
\text { on sustainability. }\end{array}$} & \multicolumn{2}{|c|}{$\begin{array}{c}\text { Formalized knowledge of information needed } \\
\text { for the customer to assess the sustainability of } \\
\text { the products. }\end{array}$} \\
\hline \multicolumn{5}{|c|}{ DESIGN PROCESS } \\
\hline $\begin{array}{c}\text { BUSINESS } \\
\text { REQUIREMENTS }\end{array}$ & $\begin{array}{l}\text { CD1 - Co-design with } \\
\text { Knowledge Management } \\
\text { Tools support }\end{array}$ & $\begin{array}{l}\text { CD2 - Definition of } \\
\text { Collection Support }\end{array}$ & $\begin{array}{l}\text { CD3 - Product Design } \\
\text { with CAD modeling } \\
\text { support }\end{array}$ & $\begin{array}{l}\text { CD4 - Process } \\
\text { planning support }\end{array}$ \\
\hline KNOWLEDGE & $\begin{array}{l}\text { Need of data sharing } \\
\text { agreements between } \\
\text { retailers, manufacturers } \\
\text { and designers but also the } \\
\text { involvement of consumers } \\
\text { through specific online } \\
\text { communities of consumer } \\
\text { target groups. }\end{array}$ & $\begin{array}{l}\text { Knowledge on the } \\
\text { specific functional } \\
\text { requirements of the } \\
\text { customers. }\end{array}$ & $\begin{array}{l}\text { Modularity, } \\
\text { Postponement, } \\
\text { Product innovation, } \\
\text { Open innovation }\end{array}$ & $\begin{array}{l}\text { New solutions in } \\
\text { terms of new process } \\
\text { plans, as well as } \\
\text { reduces the time } \\
\text { needed to reach } \\
\text { satisfactory solutions. }\end{array}$ \\
\hline ICT & $\ldots$ & $\ldots$ & $\ldots$ & $\ldots$ \\
\hline \multicolumn{5}{|c|}{ PRODUCTION PLANNING PROCESS } \\
\hline $\begin{array}{l}\text { BUSINESS } \\
\text { REQUIREMENTS }\end{array}$ & $\begin{array}{l}\text { CP1 - Customer order } \\
\text { processing support }\end{array}$ & $\begin{array}{l}\text { CP2 - Support for } \\
\text { collaborative process } \\
\text { planning }\end{array}$ & $\begin{array}{l}\text { CP3 - Support for } \\
\text { collaborative } \\
\text { production } \\
\text { planning and } \\
\text { control }\end{array}$ & $\begin{array}{l}\text { CP4 - Partner } \\
\text { monitoring and trace } \\
\text { support }\end{array}$ \\
\hline KNOWLEDGE & $\begin{array}{l}\text { (a) The analysis and } \\
\text { translation of the product } \\
\text { configuration information } \\
\text { into the production article } \\
\text { data in terms of materials } \\
\text { and production processes } \\
\text { (for lot size } 1, \text { and for } \\
\text { small series). } \\
\text { (b) Aggregation of orders. } \\
\text { (c) Partner selection in } \\
\text { order to collaborate with } \\
\text { them. }\end{array}$ & $\begin{array}{c}\text { Information already } \\
\text { stored in the PDM } \\
\text { system and related to } \\
\text { generic BOM and } \\
\text { working cycles for } \\
\text { product models. Order } \\
\text { specific information } \\
\text { that will integrate these } \\
\text { will have to be } \\
\text { coherently structured } \\
\text { according to a common } \\
\text { framework. } \\
\end{array}$ & $\begin{array}{l}\text { Impact of the right } \\
\text { or wrong production } \\
\text { on the pathologies. }\end{array}$ & $\begin{array}{l}\text { Ability to include in the } \\
\text { definition of KPIs proper } \\
\text { inputs from final } \\
\text { customers requirements } \\
\text { and needs, especially } \\
\text { the ones belonging to } \\
\text { the target groups } \\
\text { addressed by the project } \\
\text { as, for example in terms } \\
\text { of anallergic and no } \\
\text { toxic materials. }\end{array}$ \\
\hline ICT & $\ldots$ & $\ldots$ & $\ldots$ & $\ldots$ \\
\hline
\end{tabular}

\section{Conclusions and Further Research}

The ongoing European project "Customer-oriented and eco-friendly networks for healthy fashionable goods (CoReNet)" aims to provide TCFI companies with the tools and methods to face the challenge of working in demand-driven and customer oriented collaborative networks.

Until now the project research work allowed the definition of a Reference Model that set up the foundations for the development of future technologies and tools that support network operation. The following phases include the instantiation to specific companies' requirements of the reference model according to their business model in 
order to support them in the path to small series production of healthy products. The model is currently under evaluation and improvement in the CoReNet project together with the industry partners and the customers. The final goal is to provide a sound customer-oriented reference model suitable to collaborative network managers and stakeholders of TCF industry.

Acknowledgments. The research leading to these results has received funding from the European Union's Seventh Framework Programme (FP7/2007-2013) under grant agreement $n^{\circ}[260169]$.

\section{References}

1. EU Commission: The demographic future of Europe - from challenge to opportunity (2007),

http://europa.eu/legislation_summaries/employment_and_social _policy/situation_in_europe/c10160_en.htm

2. Camarinha-Matos, L.M., Boucher, X., Afsarmanesh, H.: Collaborative Networks for a Sustainable World 11th IFIP WG 5.5. In: Proceedings of Working Conference on VE (2010)

3. Christopher, M.: Logistics and supply chain management - Creating Value-Adding Networks, 3rd edn. Prentice Hall (2005)

4. Simchi-Levi, D.: Operations Rules - Delivering Customer Value through Flexible Operations. The MIT Press (2010)

5. Paul, C., James, A., Towill, D.R.: Analysis and design of focused demand chains. Journal of Operations Management 20(6), 675-689 (2002)

6. De Treville, S., Shapiro, R.D., Hameri, A.-P.: From supply chain to demand chain: the role of lead time reduction in improving demand chain performance. Journal of Operations Management 21(6), 613-627 (2004)

7. Adler, P.S.: Market, Hierarchy and Trust: the Knowledge Economy and the Future of Capitalism. Organization Science 12(2), 215-234 (2001)

8. Cohen, S., Roussel, J.: Strategic Supply Chain Management - The five disciplines for top performance. MacGraw-Hill, New York (2005)

9. Filos, E., Banahan, E.: Towards the smart organization: An emerging organizational paradigm and the contribution of the European RTD programs. Journal of Intelligent Manufacturing 12(2), 101-111 (2001)

10. Glaser, B., Strauss, A.: Grounded Theroy: the discovery of grounded theory. Aldine (1967)

11. Eisenhardt, K.M.: Building theories from case study research. Academy of Management Review 14(4), 532-550 (1989)

12. Pagell, M.: Understanding the factors that enable and inhibit the integration of operations, purchasing and logistics. Journal of Operation Management 22(5), 459-487 (2004)

13. Fornasiero, R., Chiodi, A., Carpanzano, E., Carneiro, L.: Research Issues on CustomerOriented and Eco-friendly Networks for Healthy Fashionable Goods. In: Ortiz, Á., Franco, R.D., Gasquet, P.G. (eds.) BASYS 2010. IFIP AICT, vol. 322, pp. 36-44. Springer, Heidelberg (2010) 
14. Azevedo, A., Bastos, J., Almeida, A., Soares, C., Magaletti, N., Del Grosso, E., Stellmach, D., Winkler, M., Fornasiero, R., Zangiacomi, A., Chiodi, A.: Customer-Oriented and Ecofriendly Networks for Health Fashionable Goods - The CoReNet Approach. In: Camarinha-Matos, L.M., Pereira-Klen, A., Afsarmanesh, H. (eds.) PRO-VE 2011. IFIP AICT, vol. 362, pp. 69-76. Springer, Heidelberg (2011)

15. FoF-PPP: Factories of the Future: Public, Private Partnership, Strategic Roadmap (2009)

16. Manufuture, Strategic Research Agenda (2006)

17. Osterwalder, A., Pigneur, Y.: Business Model Generation - A Handbook for Visionaries, Game Changers, and Challengers. John Wiley \& Sons, Inc., Hoboken - New Jersey (2010)

18. Osterwalder, A.: The Business Model Ontology - A Proposition in a Design Science Approach. Phd Thesis (2004)

19. Romero, D., Galeano, N., Giraldo, J., Molina, A.: Towards The Definition Of Business Models And Governance Rules For Virtual Breeding Environments Network-Centric Collaboration and Supporting Frameworks, vol. 224, pp. 103-110. Springer, Boston (2006)

20. Plantin, S.: Orange Labs R\&D internal methodology for building business models (2008)

21. Chesbrough, H., Rosenbloom, R.S.: The role of the business model in capturing value from innovation: evidence from Xerox Corporation's technology spin-off companies. Industrial and Corporate Change 11(3), 529-555 (2002)

22. Romero, D., Molina, A.: Collaborative networked organisations and customer communities: value co-creation and co-innovation in the networking era. Production Planning \& Control 22(5-6), 447-472 (2011)

23. Fornasiero, R., Zangiacomi, A., Stellmach, D.: A Reference Model for Customer-Oriented and Eco-Friendly Networks for Healthy Fashionable Goods. In: Proceedings of the APMS 2010 Stavanger, Norway (2011) 